\title{
A Research Study on Corporate Websites and Social Media in Creating Physical Evidence and Public Strategy Mix
}

\author{
Emrah Özkul \\ Asoc. Prof. Dr. \\ Kocaeli University Tourism and Hotel Management, Turkey \\ Bilsen Bilgili \\ Ass. Prof. Dr. \\ Kocaeli University Tourism and Hotel Management, Turkey
}

\begin{abstract}
The importance of social media and corporate websites in marketing of service has been increasing day by day with the development of information technologies. The comments about the experience of the service shared in social media, pictures shown the corporate websites as a physical evidence play important role for the branding of services with this study, the investigation of usage strategies of physical evidence is aimed on the purchasement decisions of consumers by decreasing the abstract disadvantage of the service. In this study, 100 hospitality businesses in tourism where sector all elements of service marketing mix used investigated. The factors used as physical evidence corporate websites of hospitality businesses and the comments of experienced consumers in social media create the data of this study. Content analysis had been made with this data. By the comparison of these two types of data, the differences between consumer service quality perception and the elements of physical evidence have been statistically tested. In the parallel of the results obtained in this research, strategic suggestions have been developed for creating successful service brand, marketing of services, creating the loyalty an higher quality perception.
\end{abstract}

\section{INTRODUCTION}

Service characteristics differ from abstractness, production and consumption indissolubility, heterogeneity and physical goods (Zeithaml, Parasuraman, Berry 1985; Berry, 2000:128). Physical goods are usually produced sold and consumed. On the contrary, services are firstly sold and produced and consumed at the same time. The perceived quality of service brand is not always the same because of the dependence of quality with human factor. Therefore, it is necessary to adapt the marketing techniques about branding used for physical goods to the services (Shostack, 1977, Gummesson 1978:89-95). The approval of a service brand by a consumer fulfills with the perceptions which created the trials of the dimensions of the service. In the contrast of physical goods, there is need of the wide evaluation process for the positive perception of service brand. Disadvantages of services caused by their abstract features are the elements of physical evidence in marketing mix by creating positive quality perception. In the brand connotation of physical goods, package, product features, slogan, and symbol are effective. Whereas, the physical characteristics of employees and service features are effective for service brands. The element of communication is very important for service brands. Because, positive public opinion and verbal communication provides easiness for the service purchasement. Similarly, trust plays on important role for the improvement of service brand. 
Opinions of experienced consumers are also important for the new, non experienced consumer in the purchasement of the service brand (Bilgili, 2007:54).

Differences in service marketing, which has gained too much importance after the 1980s, is also reflected in the tourism sector. Therefore, accommodation enterprises that form the basis of tourism industry, which produce touristic products and services, have started to develop different marketing strategies. In this sense human factor, by underlying modern marketing and taking place in all processes of service in accommodation enterprises, becomes more important (Moriarty, and Jones et al., 2008:293).

The perception of people is under the influence of many factors. One of these factors is "physical appearance". It was determined with the researches that items with effective physical appearance are persuasive and have positive effects on consumers' attitudes (Odabaşl, 1998:68). In terms of marketing, many goods/ services come into being only when they are thought to meet the needs (Cemalcilar, 1996:60). Physical evidence and interpersonal communication plays a very significant role especially with regard to creating a positive perception on the consumer for the services.

Besides other marketing mix elements, the mix of physical ones is considered to be a factor providing a non-price pricing advantage by service marketing experts. On the other hand, with this mix, the enterprise is able to be different from others in terms of certain aspects (İçöz, 2005).

The physical evidence in the service marketing of accommodation enterprises involves all material elements that evoke the hotel service in the hotel room, reception or dining hall. The order, materials used, staff uniform, printed leaflets, the colors the hotel used and tangible materials like the logo where the service is produced mean the confirmation of the service for the customer (Altunışık, R., and 2009:47). Also, the accommodation enterprise building, equipment, furniture, interior decoration and other appearances are considered to be significant components in this sense. All these pieces are important to create and shape value judgments of touristic consumers about the setting and the image of the enterprise (İçöz, 2005).

In order for service enterprises to perform successful promotional applications, the management, employees and the enterprise must embrace the marketing strategy which involves the customers. "External marketing" communication taking place between the enterprise management and the customers are quite significant. External marketing involves activities such as determining customer expectations and the promises to the customer about the service that is going to be given by the enterprise. Service enterprises present what their service promise is by promotional tools like advertisements, sales development and public relations as well as communicating with the customer via the enterprise staff and physical opportunities (Yükselen, 2007:454). Meting the expectations of the quests - the most important actor of the accommodation enterprises and creating customer value form the basis of external marketing (Kozak, 2006:49).

Promotional activities in the accommodation enterprises where touristic products are presented in the form of service, gain more importance than other industries that produce goods. The main difference between product and service marketing is that tourism and holiday products form a whole consisting of mixed values in the spots where product takes the form of service. The products in tourism sector are intangible, inseparable, various, indurable, seasonal 
and luxurious as well as having characteristics that are impossible to analyze before being purchased (Morgan and Pritchard, 2006:21).

The internet first gave service as web 1.0 and users carried out various operations without being active in this field. By entering web 2.0 period, users started to include their thoughts and designs in the internet environment. It would be correct to say that especially the understanding of social media became alive with web 2.0 (Küçükaltan and Kılıçaslan, 2013). It is possible to say that with web 3.0, that is the semantic formation which is enabled by today's technology, this understanding will show itself in many more different fields. Information and Communication Technologies have been used in tourism sector in enterprise strategies since 1970s. In those years Computerized Reservation Systems (CRS), in 1980s Global Distribution Systems, and in 1990s the internet technology and other developments influenced the relationship between the enterprises and consumers (Minazzi, 2015).

Social networks which date back to 1980s and which always show progress caused the mix of social media and classic marketing approach to give its place to "network marketing" approach (Kircova, 2008). Creating brand awareness, forming opinions for new marketing strategies, and improving the fame and the image of the brand in the social media - defined as sharing, discussing and a context to cooperate by forming extremely interactive platforms with mobile and web-based technologies (Kietzman et al., 2011) - to benefit from the crowd has become a frequent use in tourism enterprises (Kozak, Özel, Yüncü, 2005).

On the other hand, the attempt of starting mouth to mouth communication on the internet took its place as "viral marketing" in marketing literature (Argan and Argan, 2006:231). It is also possible to see terms like virutic marketing, virus marketing, buzz marketing and infectious marketing. Consumer communication networks are used in carrying out enterprise activities for product promotion and distribution. E-commerce, groups, communities and message are the main tools that the firms use to develop their promotional activities (Helm, 2000: 158161). Providing information about the product on the internet can take place in two ways. Firstly, one can get information about the product features, price, payment conditions etc. by using the webpage of the enterprise or via online advertisements. The other is getting information from other consumers who used the product by means of various platforms (forums, shopping sites, blogs, complaining sites etc.) in the internet environment. In fact this situation is "mouth to mouth communication" through the internet (Kılıçer, 2006:89). Nowadays many consumers choose blogs on the internet as a channel of mouth to mouth communication, and these blogs guide consumers in terms of the product or the service mark (Bartlett, 2006:24).

One experience that Doubletree had clearly shows the role of mouth to mouth communication via the internet on the issue in accommodation enterprises. Although having reservation, two customers who witnessed that their rooms were sold to other customers sent a presentation they prepared in the lounge to many other people by e-mail under the heading "Your hotel is pretty bad". When this e-mail was received by millions of people, the enterprise apologized, yet they couldn't prevent undergoing a serious loss (Sernovitz, 2006: 54).

Social media arose from the combination of information and communication technologies (such as mobile and web-based technologies) and social interaction which keeps people social (Zeng and Gerritsen, 2014). When considered as a whole, the term of social media contains a wide range. Bookmarking, social media news sites, social network sites, social photo and video sharing sites can be considered within this scope (Küçükaltan and Kıllaçaslan, 2013). Apart 
from that, online social travelling networks, the use of which has gained an important increase lately, have a significant impact on tourists' travelling decisions. Websites like TravBuddy.com, Travellerspoint, WAYN, Woophy, Passportstamp and Tripadvisor.com provide interaction between the local tourists and the hotels. Among these sites, Tripadvisor.com has the top usage rate (Miguens et al., 2008). With more than 290 million views, more than 126 thousand destinations and more than 950 thousand hotels, information is given on this website having a considerable effect on the preferences of touristic consumers.

\section{RESEARCH METHOD}

In this research, it is aimed to determine the effect of internet environment on physical evidence and mouth to mouth communication for accommodation enterprises. For this purpose, the websites of the accommodation enterprises were treated as the presentation place of physical evidence factors, and the blogs were regarded as the mouth to mouth communication field of customers. Physical evidence factors were determined, and 130 accommodation enterprises in different categories such as city-resort, 5-star, 3-star, and localforeign franchise hotels were researched regarding what factors they consider in their applications or whether there are differences according to these categories. By analyzing the sharings about customer satisfaction and complaints of accommodation enterprises, it was tried to determine the role of the internet environment regarding the speciousness of physical evidence factors in mouth to mouth communication. T-test was used in the analysis of the research data and differences were tried to be determined.

FINDINGS AND RESULTS

The Characteristics of Accommodation Enterprises within the Scope of the Research 130 hotels were taken into the scope of the research. The characteristics of the hotels are shown in Table 1.

Table 1. The Distribution of the Hotels Analyzed in the Research

\begin{tabular}{|c|c|c|c|}
\hline \multicolumn{2}{|c|}{$\begin{array}{c}\text { Accommodation Company } \\
\text { Structure }\end{array}$} & \multicolumn{2}{|c|}{ Number/Rate } \\
\hline & & $\mathbf{N}$ & $\%$ \\
\hline \multirow[t]{2}{*}{ Star } & 3 Star & 50 & 38,5 \\
\hline & 5 Star & 80 & 61,5 \\
\hline \multirow[t]{2}{*}{ Capital } & Domestic & 86 & 66,2 \\
\hline & Foreign & 44 & 33,8 \\
\hline \multirow[t]{2}{*}{ Status } & Independent & 72 & 55,4 \\
\hline & Chain & 58 & 44,6 \\
\hline \multirow[t]{2}{*}{ Location } & Resort & 69 & 53,1 \\
\hline & City & 61 & 46,9 \\
\hline \multicolumn{2}{|c|}{ Total } & 130 & 100 \\
\hline
\end{tabular}

When the distribution of the hotels was analyzed according to their characteristics, it was seen that $61.5 \%$ are 5 -star, $66.2 \%$ are local, $55.4 \%$ are independent and $53.1 \%$ are resort hotels.

\section{Differences in Physical Evidence Applications of the Hotels According to the Categories They Belong}

The distribution of the hotels was determined according to the use or non-use of physical evidence factors on their websites. These distributions were classified according to the star type, capital structure, status and location of the hotels. In star type, 3-star and 5-star hotels were taken into the sample. In the capital structure, local and foreign capital was distinguished. As for status, franchise and independent hotels were distinguished. In location discrimination, two groups were used as city and resort hotels. The frequencies of physical evidence factors, which are treated within the scope of the research, are given in Table 2 according to their use or non-use in the hotel categories mentioned. 
Table.2 Physical Evidence Practice of Hotels by Category

\begin{tabular}{|c|c|c|c|c|c|c|c|c|c|c|c|c|c|c|c|c|}
\hline \multirow{3}{*}{$\begin{array}{l}\text { Physical Evidence } \\
\text { Elements }\end{array}$} & \multicolumn{4}{|c|}{$\begin{array}{c}\text { According to The Star } \\
\text { Types }\end{array}$} & \multicolumn{4}{|c|}{$\begin{array}{c}\text { According to The Capital } \\
\text { Structure }\end{array}$} & \multicolumn{4}{|c|}{$\begin{array}{c}\text { According to The } \\
\text { Status }\end{array}$} & \multicolumn{4}{|c|}{ By Location } \\
\hline & \multicolumn{2}{|c|}{ 3 Star } & \multicolumn{2}{|c|}{5 Star } & \multicolumn{2}{|c|}{ Domestic } & \multicolumn{2}{|c|}{ Foreign } & \multicolumn{2}{|c|}{ Indepn. } & \multicolumn{2}{|c|}{ Chain } & \multicolumn{2}{|c|}{ City } & \multicolumn{2}{|c|}{ Resort } \\
\hline & Yes & No & Yes & No & Yes & No & Have & No & Yes & No & Yes & No & Yes & No & & No \\
\hline $\begin{array}{ll}\text { Hotel } & \text { General } \\
\text { Photo } & \\
\end{array}$ & 50 & 0 & 76 & 4 & 86 & 0 & 40 & 4 & 72 & 0 & 54 & 8 & 66 & 3 & 60 & 1 \\
\hline $\begin{array}{l}\text { Environmental } \\
\text { Photo }\end{array}$ & 40 & 10 & 73 & 7 & 75 & 11 & 38 & 6 & 61 & 11 & 52 & 6 & 61 & 8 & 52 & 9 \\
\hline Landscape Photo & 46 & 4 & 77 & 3 & 81 & 5 & 42 & 2 & 67 & 5 & 56 & 2 & 69 & 0 & 54 & 7 \\
\hline Room Photo & 50 & 0 & 80 & 0 & 86 & 0 & 44 & 0 & 72 & 0 & 58 & 0 & 69 & 0 & 61 & 0 \\
\hline Personal Photo & 34 & 16 & 27 & 53 & 49 & 37 & 12 & 32 & 42 & 30 & 19 & 39 & 40 & 29 & 21 & 40 \\
\hline TV & 49 & 1 & 79 & 1 & 86 & 0 & 42 & 2 & 71 & 1 & 57 & 1 & 69 & 0 & 59 & 2 \\
\hline Telephone & 50 & 0 & 80 & 0 & 86 & 0 & 44 & 0 & 72 & 0 & 58 & 0 & 69 & 0 & 61 & 0 \\
\hline Air Conditioning & 49 & 1 & 80 & 0 & 86 & 0 & 43 & 1 & 71 & 1 & 58 & 0 & 69 & 0 & 60 & 1 \\
\hline Mini Bar & 50 & 0 & 80 & 0 & 86 & 0 & 44 & 0 & 69 & 0 & 61 & 0 & 69 & 0 & 61 & 0 \\
\hline Elevator & 49 & 1 & 50 & 30 & 69 & 17 & 30 & 14 & 64 & 8 & 35 & 23 & 51 & 18 & 48 & 13 \\
\hline Wi-fi & 49 & 1 & 75 & 5 & 8 & 3 & 41 & 3 & 70 & 2 & 54 & 3 & 65 & 4 & 59 & 2 \\
\hline Kitchen Equipment & 50 & 0 & 79 & 0 & 86 & 0 & 44 & $\mathrm{c}$ & 71 & 0 & 58 & 0 & 68 & 0 & 61 & 0 \\
\hline Width & 34 & 16 & 74 & 6 & 70 & 16 & 38 & 6 & 52 & 20 & 56 & 2 & 58 & 11 & 50 & 11 \\
\hline Spaciousness & 29 & 21 & 66 & 14 & 59 & 27 & 36 & $\varepsilon$ & 46 & 26 & 49 & 9 & 53 & 16 & 42 & 19 \\
\hline Lighting & 30 & 20 & 69 & 10 & 63 & 23 & 36 & 8 & 46 & 26 & 53 & 5 & 56 & 13 & 43 & 17 \\
\hline Color & 32 & 18 & 74 & 6 & 64 & 22 & 42 & 2 & 50 & 22 & 56 & 2 & 59 & 10 & 47 & 14 \\
\hline Furniture & 41 & 9 & 72 & 8 & 72 & 14 & 4 & 3 & 60 & 12 & 53 & 5 & 57 & 12 & 56 & 4 \\
\hline Hygiene & 49 & 1 & 80 & 0 & 86 & 0 & 43 & 1 & 71 & 1 & 58 & 0 & 69 & 0 & 60 & 1 \\
\hline Ergono & 41 & 9 & 78 & 2 & $7 !$ & 1 & 4 & & 62 & 10 & 57 & 1 & 59 & 10 & 60 & 1 \\
\hline Services & 46 & 4 & 76 & 4 & 80 & 6 & 4 & 2 & 67 & 5 & 55 & 3 & 68 & 1 & 54 & 7 \\
\hline Car Pa & 50 & 0 & 69 & 11 & 78 & 8 & 41 & 3 & 71 & 1 & 48 & 10 & 62 & 7 & 57 & 4 \\
\hline $\begin{array}{l}\text { Transport } \\
\text { Information } \\
\end{array}$ & 50 & 0 & 80 & 0 & 86 & 0 & 44 & 0 & 72 & 0 & 58 & 0 & 69 & 0 & 61 & 0 \\
\hline $\begin{array}{l}\text { Communication } \\
\text { Infor. }\end{array}$ & 49 & 1 & 80 & 0 & 86 & 0 & 43 & 1 & 71 & 1 & 58 & 0 & 69 & 0 & 60 & 1 \\
\hline $\begin{array}{ll}\text { Multiple } & \text { Lang. } \\
\text { Options }\end{array}$ & 41 & 9 & 76 & 4 & 76 & 10 & 41 & 3 & 61 & 11 & 56 & 2 & 67 & 2 & 5 & 11 \\
\hline $\begin{array}{l}\text { Information } \\
\text { Exchange }\end{array}$ & 20 & 30 & 79 & 1 & 20 & 66 & 1 & 43 & 20 & 52 & 1 & 57 & 16 & 53 & 5 & 56 \\
\hline Electronic Bulletin & 2 & 3 & 55 & 2 & 3 & 5 & 11 & 3 & 29 & 4 & 16 & 42 & 24 & 45 & 21 & 40 \\
\hline Online Help & 20 & 30 & 11 & 69 & 25 & 61 & 6 & 3 & 23 & 49 & 8 & 50 & 23 & 46 & 8 & 53 \\
\hline Online Guest Book & 28 & 22 & 10 & 70 & 35 & 51 & 3 & 41 & 29 & 43 & 9 & 49 & 29 & 40 & 9 & 52 \\
\hline $\begin{array}{ll}\begin{array}{l}\text { Freq. } \\
\text { Question }\end{array} & \text { Asked } \\
\end{array}$ & 20 & 30 & 9 & 71 & 27 & 59 & 2 & 42 & 23 & 49 & 6 & 52 & 21 & 48 & 8 & 53 \\
\hline $\begin{array}{l}\text { Settlement } \\
\text { Information }\end{array}$ & 43 & 7 & 63 & 17 & 70 & 16 & 36 & 8 & 57 & 15 & 49 & 9 & 59 & 10 & 47 & 14 \\
\hline Room-Price Inquiry & 40 & 10 & 69 & 11 & 71 & 15 & 38 & 6 & 59 & 13 & 50 & 8 & 52 & 17 & 57 & 4 \\
\hline $\begin{array}{l}\text { Oppr. For The } \\
\text { Disabled }\end{array}$ & 20 & 30 & 12 & 68 & 25 & 61 & 7 & 37 & 24 & 48 & 8 & 50 & 22 & 47 & 10 & 51 \\
\hline Membership & 2 & 3 & 29 & 5 & & 5 & 22 & & 25 & 4 & 24 & 34 & 21 & 48 & 28 & 33 \\
\hline Help Menu & 22 & 28 & 4 & 76 & 24 & 62 & 2 & 42 & 22 & 50 & 4 & 54 & 19 & 50 & 7 & 54 \\
\hline Facebook & 42 & 8 & 71 & 9 & 76 & 10 & 37 & 7 & 62 & 10 & 51 & 7 & 62 & 7 & 51 & 10 \\
\hline Instagram & 26 & 24 & 56 & 24 & 55 & 3 & 2 & 17 & 44 & 28 & 38 & 20 & 44 & 25 & 38 & 23 \\
\hline Twitter & 35 & 15 & 66 & 14 & 64 & 22 & 37 & 7 & 52 & 20 & 49 & 9 & 55 & 14 & 46 & 15 \\
\hline Youtube & 24 & 26 & 4 & 3 & 42 & 4 & 26 & 18 & 33 & 38 & 35 & 23 & 39 & 29 & 29 & 32 \\
\hline Tripadvisc & 30 & 20 & 35 & 4 & 4 & 4 & 22 & & 38 & 34 & 27 & 31 & 38 & 31 & 27 & 34 \\
\hline Foursquare & 17 & 33 & 19 & 61 & 28 & 58 & 8 & 36 & 20 & 52 & 16 & 42 & 28 & 41 & 8 & 53 \\
\hline Virtual Tour Video & 18 & 32 & 8 & 72 & 20 & 66 & 6 & & 20 & 52 & 6 & 52 & 24 & 45 & 2 & 59 \\
\hline Trailer & 17 & 33 & 28 & 52 & 31 & 55 & 14 & 30 & 26 & 46 & 19 & 39 & 36 & 33 & 9 & 52 \\
\hline $\begin{array}{l}\text { Effective Use of } \\
\text { Media }\end{array}$ & 7 & 43 & 15 & 65 & 16 & 70 & 6 & 38 & 12 & 60 & 10 & 22 & 10 & 59 & 12 & 49 \\
\hline $\begin{array}{l}\text { Tourist } \\
\text { Communication }\end{array}$ & 40 & 10 & 45 & 35 & 60 & 26 & 25 & 19 & 58 & 14 & 27 & 31 & 47 & 22 & 38 & 23 \\
\hline
\end{tabular}

In the research, it was aimed to determine whether there are differences between using or not using the strategies of physical evidence according to the status, ownership status, location and 
capital structure of the hotels that were analyzed. For this purpose, an independent t-test was conducted. Table 3 shows the differences regarding the use of physical evidence factors by the hotels on their websites according to being a resort or city hotel.

Table 3. The Differences of the Hotels According to Being a City or Resort Hotel

\begin{tabular}{|c|c|c|c|c|c|c|c|c|}
\hline \multirow[b]{2}{*}{ Physical Evidence Elements } & \multicolumn{2}{|c|}{ Star } & \multicolumn{2}{|c|}{ Capital } & \multicolumn{2}{|c|}{ Status } & \multicolumn{2}{|c|}{ Location } \\
\hline & $\mathbf{F}$ & Sig. & $\mathbf{F}$ & Sig. & $\mathbf{F}$ & Sig. & $\mathbf{F}$ & Sig. \\
\hline Hotel General Photo & 11,548 & 0,001 & 41,816 & 0,000 & 24,50 & 0,000 & 3,245 & 0,074 \\
\hline Environmental Photo & 14,005 & 0,000 & 0,072 & 0,789 & 2,810 & 0,096 & 1,124 & 0,291 \\
\hline Landscape Photo & 4,373 & 0,038 & 0,367 & 0,546 & 3,150 & 0,078 & 46,502 & 0,000 \\
\hline \multicolumn{9}{|l|}{ Room Photo } \\
\hline Personal Photo & 0,172 & 0,679 & 14,737 & 0,000 & 4,257 & 0,041 & 3,012 & 0,085 \\
\hline TV & 0,450 & 0,503 & 17,782 & 0,000 & 0,094 & 0,760 & 9,870 & 0,002 \\
\hline \multicolumn{9}{|l|}{ Telephone } \\
\hline Air Conditioning & 6,701 & $\mathbf{0 , 0 1 1}$ & 8,256 & 0,005 & 3,310 & 0,071 & 4,684 & 0,032 \\
\hline \multicolumn{9}{|l|}{ Mini Bar } \\
\hline Elevator & 350,21 & $\mathbf{0 , 0 0 0}$ & 8,118 & 0,005 & 66,35 & $\mathbf{0 , 0 0 0}$ & 1,632 & 0,204 \\
\hline Wi-fi & 1,727 & 0,191 & 5,674 & 0,019 & 3,477 & 0,065 & 1,968 & 0,163 \\
\hline \multicolumn{9}{|l|}{ Kitchen Equipment } \\
\hline Width & 63,861 & 0,000 & 2,145 & 0,146 & 101,71 & 0,000 & 0,396 & 0,530 \\
\hline Spaciousness & 29,876 & 0,000 & 12,685 & 0,001 & 33,321 & 0,000 & 4,060 & 0,046 \\
\hline Lighting & 1,975 & 0,162 & 0,130 & 0,719 & 0,606 & 0,438 & 1,383 & 0,242 \\
\hline Color & 83,142 & 0,000 & 58,726 & 0,000 & 132,11 & 0,000 & 6,213 & 0,014 \\
\hline Furniture & 0,080 & 0,778 & 1,158 & 0,284 & 0,164 & 0,686 & 0,057 & 0,812 \\
\hline Hygiene & 6,701 & 0,011 & 8,256 & 0,005 & 3,310 & 0,071 & 4,684 & 0,032 \\
\hline Ergonomics & 50,016 & 0,000 & 34,904 & 0,000 & 32,05 & 0,000 & 36,816 & 0,000 \\
\hline Services & 1,891 & 0,171 & 1,208 & 0,274 & 0,695 & 0,406 & 27,419 & 0,000 \\
\hline Car Park & 44,431 & 0,000 & 0,939 & 0,334 & 61,023 & 0,000 & 2,171 & 0,143 \\
\hline \multicolumn{9}{|l|}{ Transport Information } \\
\hline Communication Information & 6,701 & 0,011 & 8,256 & 0,005 & 3,310 & 0,071 & 4,684 & 0,032 \\
\hline Multiple Language Options & 25,874 & 0,000 & 3,145 & 0,079 & 24,647 & 0,000 & 43,886 & 0,000 \\
\hline Information Exchange & 575,50 & 0,000 & 68,900 & 0,000 & 147,20 & 0,000 & 26,015 & 0,000 \\
\hline Electronic Bulletin & 3,441 & 0,066 & 13,365 & 0,000 & 9,171 & 0,003 & 0,007 & 0,933 \\
\hline Online Help & 42,475 & 0,000 & 19,925 & 0,000 & 28,202 & 0,000 & 35,422 & 0,000 \\
\hline Online Guest Book & 58,007 & 0,000 & 168,08 & 0,000 & 46,132 & 0,000 & 54,327 & 0,000 \\
\hline Frequently Asked Question & 58,639 & 0,000 & 106,43 & 0,000 & 47,110 & 0,000 & 26,325 & 0,000 \\
\hline Settlement Information & 4,600 & 0,034 & 0,014 & 0,907 & 2,459 & 0,119 & 6,213 & 0,014 \\
\hline Room-Price Inquiry & 3,433 & 0,066 & 1,283 & 0,259 & 1,743 & 0,189 & 41,932 & 0,000 \\
\hline Opportunities For The Disabled & 36,397 & 0,000 & 13,372 & 0,000 & 32,546 & 0,000 & 18,525 & 0,000 \\
\hline Membership & 0,665 & 0,416 & 6,962 & 0,009 & 2,144 & 0,146 & 9,495 & 0,003 \\
\hline Help Menu & 191,45 & 0,000 & 74,882 & 0,000 & 70,925 & 0,000 & 24,629 & 0,000 \\
\hline Facebook & 2,380 & 0,125 & 1,806 & 0,181 & 0,372 & 0,543 & 4,493 & 0,036 \\
\hline Instagram & 9,123 & 0,003 & 0,308 & 0,580 & 1,075 & 0,302 & 0,118 & 0,732 \\
\hline Twitter & 10,343 & 0,002 & 7,187 & 0,008 & 12,288 & 0,001 & 1,357 & 0,246 \\
\hline Youtube & 0,461 & 0,498 & 2,813 & 0,096 & 2,130 & 0,147 & 0,950 & 0,332 \\
\hline Tripadvisor & 0,743 & 0,390 & & & 0,023 & 0,879 & 0,023 & 0,880 \\
\hline Foursquare & 5,746 & 0,018 & 15,104 & 0,000 & 0,002 & 0,962 & 61,309 & 0,000 \\
\hline Virtual Tour Video & 56,348 & 0,000 & 7,701 & 0,006 & 30,685 & 0,000 & 201,09 & 0,000 \\
\hline Trailer & 0,054 & 0,816 & 0,981 & 0,324 & 0,640 & 0,425 & 66,030 & 0,000 \\
\hline
\end{tabular}

According to the results of the research, it was determined that there are statistically significant differences between 3-star and 5-star hotels in terms of the use of physical evidence factors on websites. When these differences were analyzed, it was seen that 5-star hotels stand out with physical evidence factors like the photo of the environment, photo of the view, airconditioning, width, spaciousness, color, hygiene and ergonomics. It was seen that 5-star hotels come to the forefront in terms of web page tools as contact information, multi-language option and Instagram account usage as well. On the other hand, 3-star hotels stand out only in terms of elevator, opportunities for disabled and parking lot with regard to physical factor emphasis. However, it was seen that 3-star hotels give more place to factors like currency information, online help, online guestbook, frequently asked questions, information on residential area, 
opportunities for disabled, help menu, Twitter account, virtual tour video and Foursquare account compared to 5-star hotels.

It was seen that there are differences in the use of physical evidence factors on the websites of accommodation enterprises according to being domestic or foreign-capitalized. When these differences were analyzed, it was seen that local enterprises are more dominant in terms of the emphasis on the overall photo of the hotel, photo of the staff, TV, air-conditioning, hygiene and opportunities for the disabled. It was seen that local enterprises use contact information, currency information, online help, online guestbook, frequently asked questions, help menu, Instagram account, foursquare account and virtual tour video much more among other services of the webpage. It was seen that foreign hotels bring the $\mathrm{Wi}-\mathrm{Fi}$, spaciousness, color, ergonomics and parking lot aspects forward in a dominant way in terms of physical evidence factor emphasis. On the other hand, multi-language option, residential area information and twitter account application are more dominant on the webpages of foreign-capitalized hotels compared to local enterprises.

It was also determined that accommodation enterprises have differences in their physical evidence factor emphasis in terms having an independent or a chain status. When the results were analyzed, it was seen that more emphasis is given to the overall photo of the hotel, photo of the staff, elevator, parking lot and opportunities for disabled in independent hotels. However, the emphasis on width, spaciousness, color and ergonomics is more dominant in chain enterprises. In web applications, the ones like currency information, e-bulletin, online help, online guestbook, frequently asked questions, help menu and virtual tour video are used more dominantly in independent hotels. On the other hand, it was seen that chain hotels stand out in the use of multi-language option and Twitter account.

It was seen that there are differences in the physical evidence factor emphasis of accommodation enterprises in terms of being a resort or city hotel. When the results of the research were analyzed, it was seen that city hotels were used much more in terms of the photo of the view, TV, air-conditioning, spaciousness, hygiene, services and opportunities for disabled. As for the ergonomics emphasis, it was seen that resort hotels come to forefront. City hotels are more dominant in terms of the use of webpage factors such as contact information, multi-language option, currency information, online help, online guestbook, residential area information, help menu, Facebook, Foursquare account, virtual tour video and promotional video. As for the affordable rooms, price inquiry and membership factors, resort hotels were found to be more dominant. According to the results of the research, H1 hypothesis is accepted. In other words, hotels show differences in the use of physical evidence applications according to the category they belong.

\section{Sharings of the Customers on Blogs Regarding the Physical Factors of the Hotels}

In the research, positive and negative comments of the customers on the physical evidence factors which accommodation enterprises emphasized on their web pages were analyzed, and the results are shown in Table 4. 
Table 4. Consumer Attitudes towards Physical Evidence Factors of Accommodation Enterprises

\begin{tabular}{|c|c|c|c|c|c|c|c|c|c|c|c|}
\hline \multirow{2}{*}{\multicolumn{2}{|c|}{$\begin{array}{c}\text { Accommodation Company } \\
\text { Structure } \\
\end{array}$}} & \multicolumn{2}{|c|}{ Hygiene } & \multicolumn{2}{|c|}{ Location } & \multicolumn{2}{|c|}{ Employees } & \multicolumn{2}{|c|}{ Comfort } & \multicolumn{2}{|c|}{ Opportunities } \\
\hline & & Good & Bad & Good & Bad & Good & Bad & Good & Bad & Good & Bad \\
\hline \multirow[t]{2}{*}{ Star } & 3 Star & 5 & 0 & 40 & 1 & 5 & 1 & 0 & 14 & - & 34 \\
\hline & 5 Star & 31 & 3 & 34 & 14 & 1 & 33 & 14 & 2 & - & 28 \\
\hline \multirow[t]{2}{*}{ Capital } & Domestic & 22 & 1 & 56 & 8 & 5 & 15 & 3 & 15 & - & 47 \\
\hline & Foreign & 14 & 2 & 18 & 7 & 1 & 19 & 11 & 1 & - & 15 \\
\hline \multirow[t]{2}{*}{ Status } & Independent & 14 & 1 & 51 & 7 & 6 & 8 & 1 & 42 & - & 42 \\
\hline & Chain & 22 & 2 & 23 & 8 & 0 & 26 & 13 & 20 & - & 20 \\
\hline \multirow[t]{2}{*}{ Location } & Resort & 15 & 3 & 46 & 5 & 5 & 23 & 3 & 6 & 3 & 32 \\
\hline & City & 21 & 0 & 28 & 10 & 1 & 11 & 11 & 10 & 11 & 30 \\
\hline
\end{tabular}

- When the results were analyzed, consumer comments on the website, where the data is gathered about the hotels for the research, were treated as positive and negative comments. When these data were analyzed, they were grouped under 5 main categories. These categories are hygiene, location, employees, comfort and opportunities.

- In the hygiene category, it was seen that customers had a positive attitude in general for all of the categories of accommodation enterprises.

- In the location category, an apparent dissatisfaction was seen in 5-star and city hotels. On the other hand, it was seen that there was an obvious satisfaction for the category of location in 3-star hotels. It is thought that this stems from the fact that expectations from 3-star hotels are low and that's why satisfaction is high.

- In the employee category, it was seen that there was a considerable dissatisfaction for the all categories of accommodation enterprises. Some of the outstanding results are as follows; there was dissatisfaction in 5-star, foreign-capitalized, chain and resort hotels to a clear extent. As for the 3-star hotels, it was seen that satisfaction was high, and this stemmed from either low expectations or warm relationships and communication since these kinds of hotels are family-owned businesses.

- In the comfort category, it was seen that satisfaction in 5-star and foreign-capitalized hotels is higher. In 3-star and independent hotels, there was dissatisfaction to a considerable extent.

- In the opportunities category, it was seen that there was dissatisfaction in all of the hotels and that this dissatisfaction is lower only in the city hotels.

- On the whole, it is possible to say that there are significant differences between the promises of accommodation enterprises and consumer perception when the emphasis of physical evidence factors in the internet environment and satisfaction expressions of consumers are compared. In other words, hotels raise consumer expectations by their physical evidence factor emphasis in the internet environment, and therefore consumers whose expectations are not met, have a high dissatisfaction. It can be seen that there is compatibility between the expectation created by the physical evidence factors and the satisfaction in all categories in terms of hygiene and location. There is inconsistency in terms of comfort in all of the hotels except for 5-star and big foreigncapitalized hotels. As an explanation to this situation, it can be said that an imitation method was used while the web pages were being designed, the present condition of the hotel was exaggerated, and the photos were deceptive. It is also possible to say that there was a clear dissatisfaction in the employee and opportunities category in all of the enterprises since all visual factors used as physical evidence were misleading, and created unrealistic expectations on consumers' minds.

According to the results of the research $\mathrm{H} 2$ hypothesis is accepted. In other words, there are differences between the expectations created by physical factors that are emphasized in the internet environment and the satisfaction of the consumers towards physical evidence factors 
which become the subject of their mouth to mouth communication in the internet environment.

\section{SUGGESTIONS}

Suggestions based on the results of the research are as follows;

- Photos and visuals presented as physical factors regarding the services of accommodation enterprises need to be realistic, and these enterprises should maintain a true attitude in terms of web applications. Enterprises, whether on purpose or not, cause consumers to have high expectations for their services. The level of consumer satisfaction decreases when his/her expectations are high and when the service of the enterprise below expectation level. Therefore, it is quite important to avoid misleading visuals and use the ones that reflect the reality instead. They need to give importance to using presentations that reflect the present condition for lighting, color, width and spaciousness emphasis instead of imitation applications.

- When the comments of the consumers in the internet environment were analyzed, it becomes striking that they refer to the visuals accommodation enterprises presented on their web pages and share their experiences. This situation means that the comment of the consumer can become effective on other consumers when the comments for satisfaction are presented through matching these with physical evidence. It was seen that accommodation enterprises did not edit or update their web pages after analyzing consumer comments. Answering consumer comments in the internet environment and editing the visuals regarding misleading physical evidence will be useful. It would also be to the point if these editing was explained in these environments. In this way, a physical evidence will be presented showing that a strong customer relationship management is realized. In this sense, the advantage provided by the internet environment can be considered as an opportunity.

- The negative dominant attitude towards the employees in consumer comments shows that human resources in the enterprises should concentrate on improving their infrastructure. It was seen that the visuals they used for their staff on their web pages and their present applications are in conflict with each other. Therefore, it is thought that enterprises should either use real visuals for their staff as physical factors on their web page or not use visuals at all. In this sense, it would be better to emphasize the trainings and activities to fix the problems regarding the complaints about the employees instead of using visuals.

- When the importance of social media is considered in daily life, it will also be useful to make some suggestions to future researchers for future subjects. Thorough studies should be carried out concerning the categories of accommodation enterprises, analyses should be done on specific examples and face to face questionnaires should be made with consumers. Also, the perception and the expectation created on the minds of consumers by physical evidence visuals in the internet environment can be compared with the present applications in the accommodation enterprises, and the accordance between these can be researched on-site.

\section{References}

Altunışık, R. (2009) Turizm İşletmelerinde Pazarlamanın Temelleri ve İki Farklı Pencereden Pazarlama Yönetimi: Üretici ve Tüketici Bakış Açısı", Turizm İşletmelerinin Pazarlanmasında 7P ve 7C, Ed. Cevdet Avcıkurt, Şehnaz Demirkol, Burhanettin Zengin, İstanbul, Değişim Yayınları.

Argan, M. \& Argan, T. (2006) Viral Marketing or Word of Mouth Advertising on Internet: A Theoretical Framework, Sosyal Bilimler Dergisi, (2), 231-250.

Bartlett, M. (2006) Blog: The New Word of Mouth, the Credit Union Journal, November 13, 24. 
Berry, L.L. (2000) Cultivating Service Brand Equity, Journal of the Academy of Marketing Science 28 (1), 128-37.

Bilgili, B. (2007) Sigorta Hizmetlerinde Marka Değeri (Hayat Sigortası Müşterileri Üzerine Bir Uygulama, Atatürk Üniversitesi Sosyal Bilimler Enstitüsü İşletme Anabilim Dalı, Üretim Yönetimi ve Pazarlama Bilim Dalı, Doktora Tezi: Erzurum.

Yükselen, C. (2007) Pazarlama, İlkeler-Yönetim-Örnek Olaylar, Ankara: Detay Yayıncılı.

Cemalcılar, İ. (1996) Pazarlama, Kavramlar-Kararlar. İstanbul: Beta Basım Yayım Dağıtım.

Gummesson, E. (1978) Toward a Theory of Professional Service Marketing, Industrial Marketing Management 7 (2), 89-95.

Helm, S. (2000) Viral Marketing-Establishing Customer Relationship by 'Word of Mouse'. Electronic Markets 10 (3), 158-161.

İçöz, O. (2005) Hizmet Parlaması, Ankara: Turhan Kitabevi.

Jane M.; Jones, R.; Rowley, J. \& Teahan, B. (2008) Marketing in Small Hotels: A Qualitative Study, Marketing Intelligence and Planning, 26 (3), 293-315.

Kılıçer, T. (2006) Tüketicilerin Satın Alma Kararlarında Ağızdan Ağıza İletişimin Etkisi: Anadolu Üniversitesi Öğretim Elemanları Üzerinde Bir Araştırma Basılmamış, Yüksek Lisans Tezi, and Anadolu Üniversitesi Sosyal Bilimler Enstitüsü: Eskişehir.

Kırcova, İ. (2008) İnternette Pazarlama. İstanbul: Beta Yayınları.

Kozak, N. (2006) Turizm Pazarlaması, Ankara: Detay Yayınevi.

Kietzmann, J.H.; Hermkens, K.; McCarthey, I.P. \& Silvestre, B.S. (2011) Social media? Get Serious, Understanding the functional building blocks of social media, Business Horizons, 54, 241-251.

Kozak, N.; Özel, Ç. H. \& Yüncü, D. K. (2011) Hizmet Pazarlaması, Ankara: Detay Yayıncılı.

Küçükaltan, D. \& Kılıçaslan, E. (2013) Turizmde Güncel Konu ve Eğilimler İçinde, Turizmde Sosyal Medya Yönetimi, Turizmde Güncel Konu ve Eğilimler, Ed: Şule Aydın Tükeltürk, Mustafa Boz, Ankara: Detay Yayıncılık.

Miguens, J, Baggio, R. \& Costa C. (2008) Social Media and Tourism Destinations: Tripadvisor Case Study, IASK ATR2008, Advances in Tourism Research, Aveiro, Portugal.

Minanzi, R. (2015) Social Media Marketing in Tourism and Hospitality, London: Springer.

Morgan, N. \& Pritchard, A. (2006) Turizm Sektöründe Reklamcılık (Çev.Deniz Demirtaş), İstanbul: MediaCat Yayınları.

Moriarty, J.; Jones, R.; Rowley, J. \& Teahan, B.K. (2008) Marketing in Small Hotels: A Qualitative Study, Marketing Intelligence \& Planning, 26 (3). 293-315.

Parasuraman, A.; Zeithaml V.A. \& Berry L.L. (1988) Servqual: A Multiple-Item Scale for Measuring Consumer Perceptions of Service Quality, Journal of Retailing, 64 (1). 12-40.

Sernovitz, A. (2006) Word Of Mouth Marketing, USA: Kaplan Publishing.

Shostack L. G. (1977), Breaking free from product marketing, Journal of Marketing, 41, 73-80.

www.tripadvisor.com/PressCenter-c4-Fact_Sheet.html

Zeng, B. \& Gerritsen, R. (2014). What do we know about social media in tourism? A review, Tourism Management Perspectives 10, 27-36. 